\title{
Detection of plasmid DNA profile in bacterial and fungal isolates from catheterizeds patients and its relation with antibiotic susceptibility
}

تحديدالمحتوى البلازميدي في البكتريا والفطريات المعزوله من مرضى انابيب القثطره وعلاقته

Raghada S. Makia Munera Ch. Ismail* Ayad M.A. Fadhil

College of Science/ AL-Nahrain University

*Tropical Biological Research Unit/ Baghdad University

$$
\text { رغدة سعد مكية }
$$

Abstract

Study the resistance of bacterial and fungal isolates which identified previously towards different antibiotics that have been recommended for treating those patients. It was found that higher percentage of resistance to penicillin, gentamycin, tetracyclin, chlormphenicol, and trimethoprim- sulfmethazxol then moderate resistance to ampcillin, nalidixic acid, cephotaxime, streptomycin, cephalexin, rifampicin and less resistance to ciprofloxacin that represent the most effective antibiotic against uropathogenic bacteria. Ketazole antibiotic was used against yeasts, which the minimum inhibitory concentration of ketazole against $83 \%$ of Candida. albicans isolates was $128 \mu \mathrm{g} / \mathrm{ml}$, the rest of the isolates was 64 $\mu \mathrm{g} / \mathrm{ml}$. Isolation of bacterial and yeasts DNA (chromosome + plasmids), results of DNA isolation showed that bacterial isolates (E.coli (RS1), proteus. mirabilis (RS2), klebsiella. pneumonia (RS3) and Pseudomonas. aeruginosa (RS4) have chromosome and plasmids vary in numbers and size according to isolate. While yeast (C13) isolate have only chromosome without plasmid.

A result of curring shows that:

-Resistance to ampicillin, tetracycline, gentamycin, pencillin for all bacterial isolates carried on plasmid.

- Resistance to cephalexin by RS1 isolate, resistance to cephotaxim by RS3 isolate and resistance to chlormphnicol by RS4 isolate carried on plasmid, while resistance to other antibiotics were carried on chromosome.


Proteus. mirabilis (RS2), Klebsiella.

Key words: plasmid, DNA profile, catheter, bacterial, fungal, antibiotic susceptibility

البحث مستل من اطروحة الماجستير للباحث الاول 
العدد والنوع بينما عزله الخميره C13 تمتلك فقط كروموسوم وغير ممتلكه للبلازميدات، واظهرت نتائج تجربة

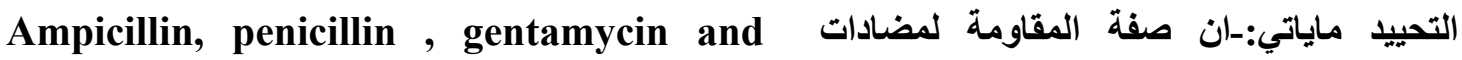
tetracycline

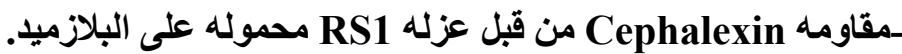

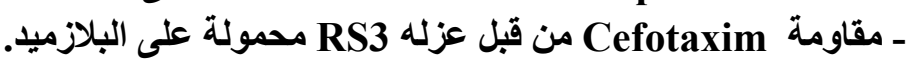

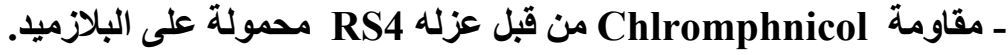

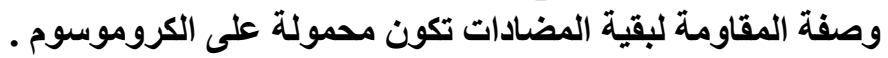

\section{Introduction}

Urinary tract infection is an extremely common clinical problem and can be defined as the presence of microorgansims in a properly collected urine samples. Virulence factors trigger infection and symptoms which play important role to help physicians in diagnosis of UTIs and patients treatment [1].

The most common uropathogens which responsible for UTIs are: members of Enterobacteriacea, Staphylococcus spp. and Candida spp. because they have different virulence factors enable them to invade urinary system and cause infection [2].

Catheter-associated urinary tract infection (CAUTI) is an infection from using tubes (catheters) that drain urine from the body. The diagnosis of catheter-associated urinary tract infection can be made when the urine culture shows 100 or more CFU per $\mathrm{ml}$ of urine from a catheterized patient. The microbiology of catheter-associated urinary tract infections includes different members of Enterobacteriacea, Staphylococcus spp., Pseudomonas spp. and Candida spp. The bacterial distribution reflects the nosocomial origin of the infections because many of the uropathogens are acquired exogenously via manipulation of the catheter and drainage device [3, 4].

Catheter associated urinary tract infections are the commonest nosocomial infections worldwide. While they are often asymptomatic and frequently cost less than nosocomial surgical site infections or nosocomial pneumonia, they are major reservoirs of antimicrobial resistant pathogens. Numerous strategies have been devised in an attempt to reduce the incidence of CAUTI, but few have proven effective. Novel technologies such as the potential use of antiseptic or antimicrobial coatings on catheters hold promise for possibly reducing these infections in the fight against antimicrobial resistance [5].

The appearance of Candida in the urine is an increasingly common complication of catheterization, particularly for patients in the intensive care unit, on broad-spectrum antimicrobials, or with underlying diabetes mellitus. C. albicans is still the most common isolate, although C. glabrata and other non-albicans species are also frequently isolated. The clinical presentation can vary from an asymptomatic laboratory finding to sepsis [6].

Antibiotics are biochemical compounds naturally produced by certain types of microorganism (bacteria and fungi) that inhibit the growth or kill other microorganism [7]. Different types of antibiotics are discovered, some of them classified as broad spectrum antibiotic which effect on a wide range of bacteria (Gram positive and Gram negative), while others classified as narrow spectrum antibiotics effected on a limited type of microorganisms [8]. 
Certain types of bacteria are inherently resistant to the effect of particular antibiotic, this is called innate or intrinsic resistance, while resistance of other bacteria to antibiotic types considered as acquired resistance which may result through spontaneous mutation or the acquisition of new genetic information $[9,10]$.

The evaluation of bacterial antibiotic resistance depend on many factors such as type of chemical structure of antibiotic, drug mode of action, period of use, type of bacteria and its ability to develop it's resistance mechanism against particular antibiotic [11].

A plasmid is a DNA molecule separate from the chromosomal DNA and capable of autonomous replication. It is typically circular and double-stranded. It usually occurs in bacteria. There may be one copy for large plasmids to hundreds of copies of the same plasmid in a single cell, or even thousands of copies for certain artificial plasmids selected for high copy number. A plasmid contains genes normally not essential for cell growth or survival, some plasmids can integrate into the host genome, be artificially constructed in the laboratory and serve as vectors (carriers) in cloning $[12,13,14]$.

Aims of the study

1-Detection the resistance pattern of isolates to antimicrobial agents.

2-Study plasmid profile of isolates and their relationships with antimicrobial resistance.

\section{Materials and methods}

Collection, Isolation and identification of bacteria [15].

Antibiotic sensitivity test of bacteria isolates [16].

Sensitivity of bacterial isolates were tested toward antibiotics (Ampicillin (AM), Cefotaxime (CTX), Cephalexin (CL), Chloramphenicol(C), Ciprofloxacin (CIP), Gentamicin (CN), Nalidixic acid (NA), Pencillin (P), Rifampicin (RA), Strteptomycin (S), Tetracycline (TE), Trimethoprim- Sulfmethaxazol (SXT)) by using the modified disc diffusion method.

Ten $\mathrm{ml}$ of nutrient broth medium was inoculated with bacterial isolate, and incubated at $37^{\circ} \mathrm{C}$ for 18 hours, $0.1 \mathrm{ml}$ of freshly prepared broth was transfered $\left(1.5 \times 10^{8}\right) \mathrm{CPU}$ (Growth of bacteria was monitored by McFarland tube No. 5 turbidity standard, which is equivalent to bacterial concentration for inoculum $1.5 \times 10^{8}$ organism/ ml) to Mullar-Hinton agar plate and streaked by sterile cotton swab three times by rotating the plate approximately $60 \mathrm{~mm}$ between each streaking to ensure even distribution of the inoculums, the inoculated plates were placed at room temperature for 10 minutes to allow absorption of excess moisture, then antibiotic disks were applied by sterile forceps on the surface of plates and incubated at $37^{\circ} \mathrm{C}$ for 18 hours in an inverted position. After incubation, the inhibition zone diameter was measured by ruler which indicates the sensitivity of bacteria to that antibiotic and the result were compared with [17].

Sensitivity of Candida albicans isolates to antifungal agent and the determination of minimum inhibition concentration (MIC) [18].

A volume ten $\mathrm{ml}$ of SDB media were inoculated by 33 isolates of Candida albicans and incubated at $37^{\circ} \mathrm{C}$ for (24-48) hrs. After incubation period, their stationary phases were determined by spectrophotometer 20 through estimating the optical density (O.D. 
$490 \mathrm{~nm}$ ) in range from (1.0-1.2). Then serial dilutions were made to obtain $10^{5}$ cell $/ \mathrm{ml}$. In other hand, Ketazole was diluted to prepare different concentrations (two dilution) which were $(4,8,16,32,64,128,256,512,1024,2048) \mu \mathrm{g} / \mathrm{ml}$. All these dilution were made in tubes containing SDB at final volume $5 \mathrm{ml}$ in each tube. $0.05 \mathrm{ml}$ SDB of $10^{5}$ cell $/ \mathrm{ml}$ were added to each tube, then incubated at $37^{\circ} \mathrm{C}$ for $48 \mathrm{hrs}$. The result was recorded by determining the activity of antifungal drugs on Candida isolates. The suitable concentration was cultured on SDA. After incubation period $48 \mathrm{hrs}$ at $37^{\circ} \mathrm{C}$, the result was recorded and compared with the control (SDB with Candida isolates) to determine the minimum inhibition concentration of the antifungal used.

\section{Plasmid DNA isolation}

Plasmid DNA isolated according to the method described by [19].

The determination of DNA was done according to [20].

\section{Agarose gel electrophoreses}

Agarose gel was prepared as described by [20].

\section{Curing of plasmid DNA}

Curing experiment was performed by using Ethidium bromide according to [21, 22].

\section{Results and discussion}

\section{Antibiotic sensitivity of bacterial isolates:}

The emergence of prevalence of antibiotic resistance strains is considered as a major therapeutic problem that can be explained by several hypothesis such as the influence of excessive and / or inappropriate antibiotic use [23].

The disk diffusion method was used to determine the sensitivity of E.coli, P. mirabilis, $K$. pneumonia and $P$. aeruginosa to different antibiotics. Result showed all isolates were resistant to antibiotic figure (1). The antibiotic resistance among isolates varied according to the genus and species of isolates and to the nature of antibiotics. In general, the isolates were highly resistant to Penicillin (P), Gentamicin (CN), Tetracycline (TE), Chloramphenicol (C) and Trimethoprim- Sulfmethaxazol (SXT). They were moderate in their resistance to Ampicillin (AM), Nalidixic acid (NA), Cephalexin (CL), Strteptomycin (S), Cefotaxime (CTX) and Rifampicin (RA), that were sensitive to each antibiotics, especially to Ciprofloxacin .

However, penicillin was the most effective antibiotic which represent $92.20 \%$ of all isolates, this is due to the lack of penicillin binding proteins (PBPs) or the microorganism could change their permeability to the drug [24].

All isolates were resistant to gentamicin and tetracycline which represent $90.47 \%$, on other hand chloramphenicol and trimethoprim-Sulfmethaxazol which represent $80.51 \%$; these results were in agreement with [25] who found that their isolates were resistant to the same antibiotics. 


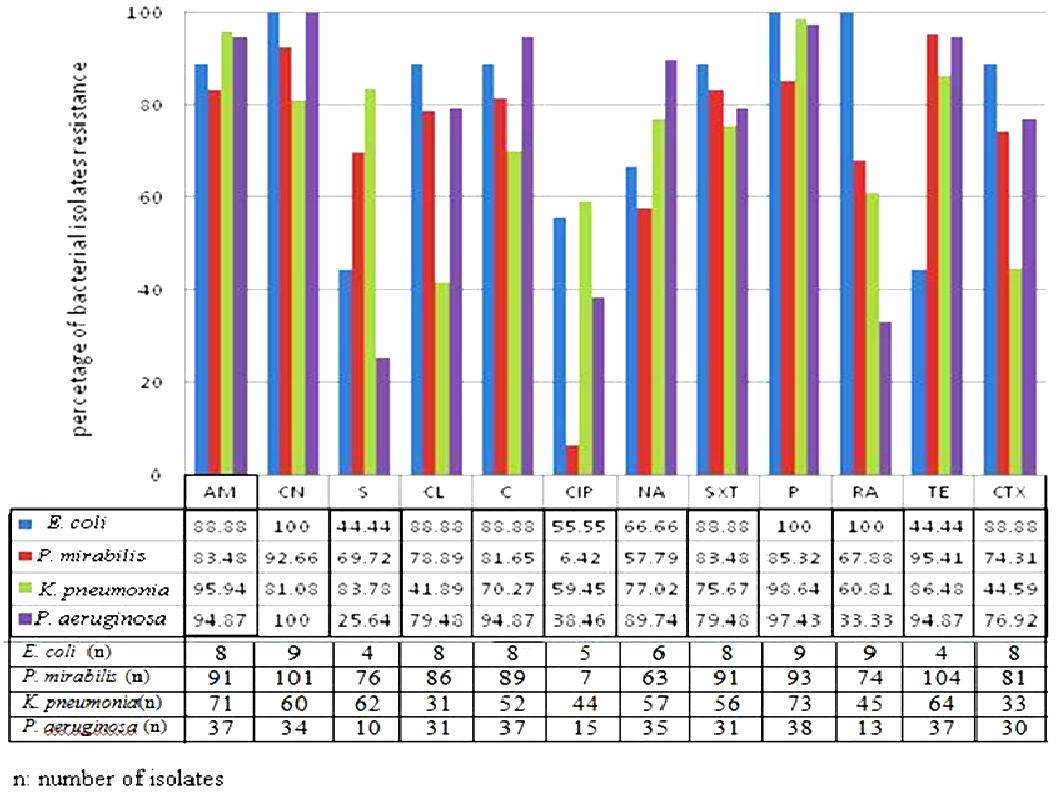

Fig (1): The percentage of antibiotic resistance of bacterial isolates.

\section{Antifungal Sensitivity of yeast}

\section{Determination of minimum inhibitory Concentration (MIC)}

In this study, ketazole was used as an antifungal agent due to its remarkable inhibitory effect on Candida albicans isolate (C13), which was highly the producer of the germ tubes. Figure (2) shows that among the 33 isolates of Candida albicans, (C13) isolate was the highest producer of germ tubes from the budding cell with a number of $\left(85 \times 10^{-4}\right)$. For this reason, it was chosen for further studies.

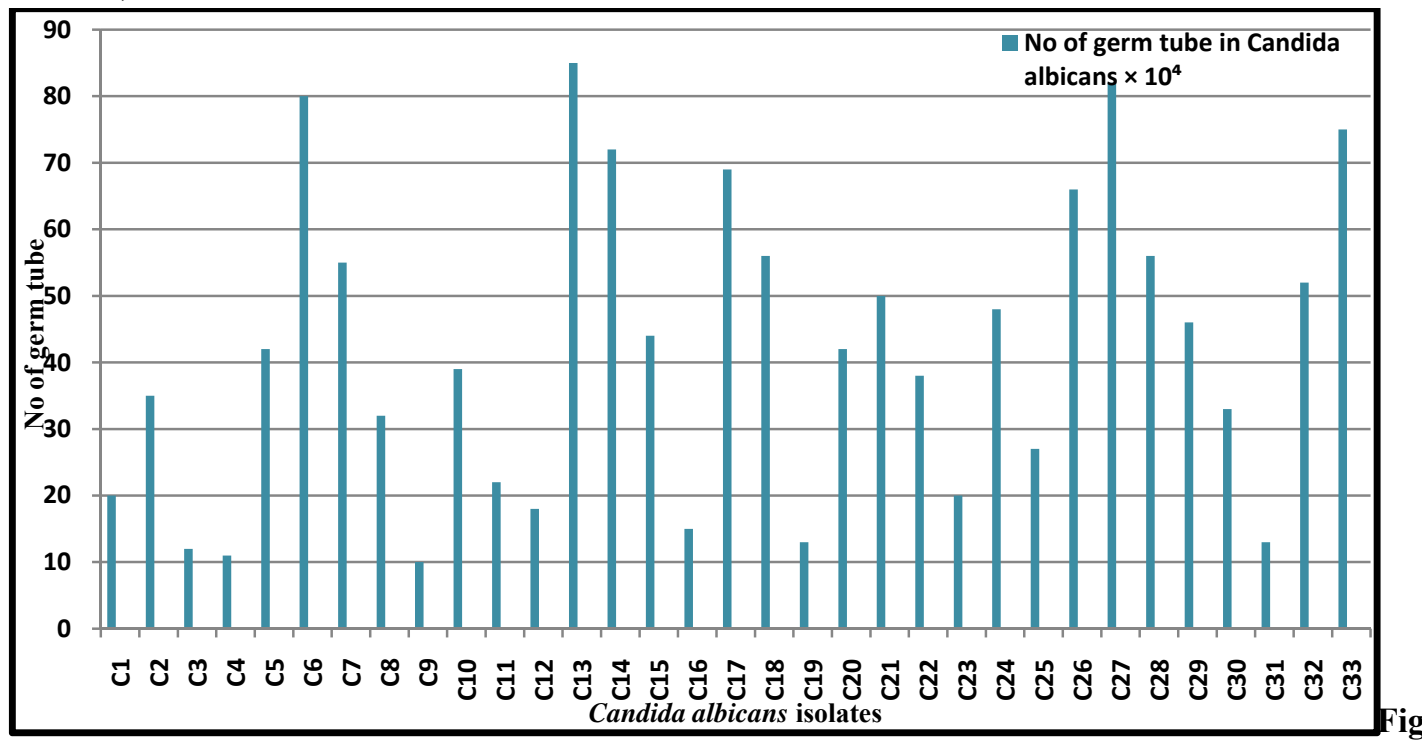

Figure (2): Ability of Candida albicans isolates to form germ tube in human serum.

The minimum inhibitory concentration (MIC) of ketazole was $128 \mu \mathrm{g} / \mathrm{ml}$ in SDB against 28 isolates of $C$. albicans, where as the rest five C. albicans isolates MIC of ketazole were $64 \mu \mathrm{g} / \mathrm{ml}$.

\section{Plasmid Profile}

Plasmid profile of different locally isolates (E. coli, P. mirabilis, K. pneumonia and $P$. aeruginosa) were studied in order to know the role of plasmid DNA in the resistance 
of these isolates to different antibiotics. Plasmid DNA was extracted according to the modified alkaline lysis method described by [26].

To determine the plasmid profile of the efficient isolates, (RS1,RS2,RS3 and RS4), antibiotic resistance of these isolates to different antibiotics was studied. Results mentioned in Table (1) showed that RS1, RS2, RS3 and RS4 were resistant to nine, seven, seven and eight antibiotics respectively.

Table (1): Antibiotic resistance of selected bacterial isolates for plasmid isolation

\begin{tabular}{cl}
\hline $\begin{array}{c}\text { Bacterial } \\
\text { isolates }\end{array}$ & \multicolumn{1}{c}{ Antibiotic resistance } \\
RS1 & AM,CN,CL,C,NA,SXT,P,TE,CTX \\
RS2 & AM,CN,S,C,SXT,P,TE \\
RS3 & AM,CN,C,SXT,P,TE,CTX \\
RS4 & AM,CN,CL,C,SXT,P,TE,CTX \\
\hline
\end{tabular}

Plasmid profile of these isolates shown in figure (3) revealed that RS1 isolate harboring four plasmid which were named as follows (pRS11, pRS12, pRS13 and pRS14).

The size of pRS11 and pRS12 ranged from (8-10)kbp, while pRS13 size ranged from (5-6)kbp and pRS14 about 3kbp.

RS2 isolate represented three plasmid which were named as follows (pRS21, pRS22 and pRS23). pRS21 and pRS22 sizes ranging from (8-10)kbp, while pRS23 size ranging from (3-4)kbp.

RS3 isolate represented also three different plasmid bands which were named as follows (pRS31, pRS32 and pRS33). It was found that the mwt. of pRS31 about (810)kbp, pRS32 about (4-5)kbp and pRS33 about (2.5-3)kbp.

RS4 isolate harboring seven bands which were named as (pRS41, pRS42 pRS43, pRS44, pRS45, pRS46 and pRS47). Size of pRS41 and pRS42 ranged from (8-10)kbp, pRS43 size about 4kbp, while pRS44 size ranged from (2.5-3)kbp. pRS45 size about (1.5-2)kbp, finally pRS46 and pRS47 had a molecular weight ranged from (0.751)kbp.

The bacterial isolates tested in this study may contain other plasmids which were not detected (may be because of its large size). 


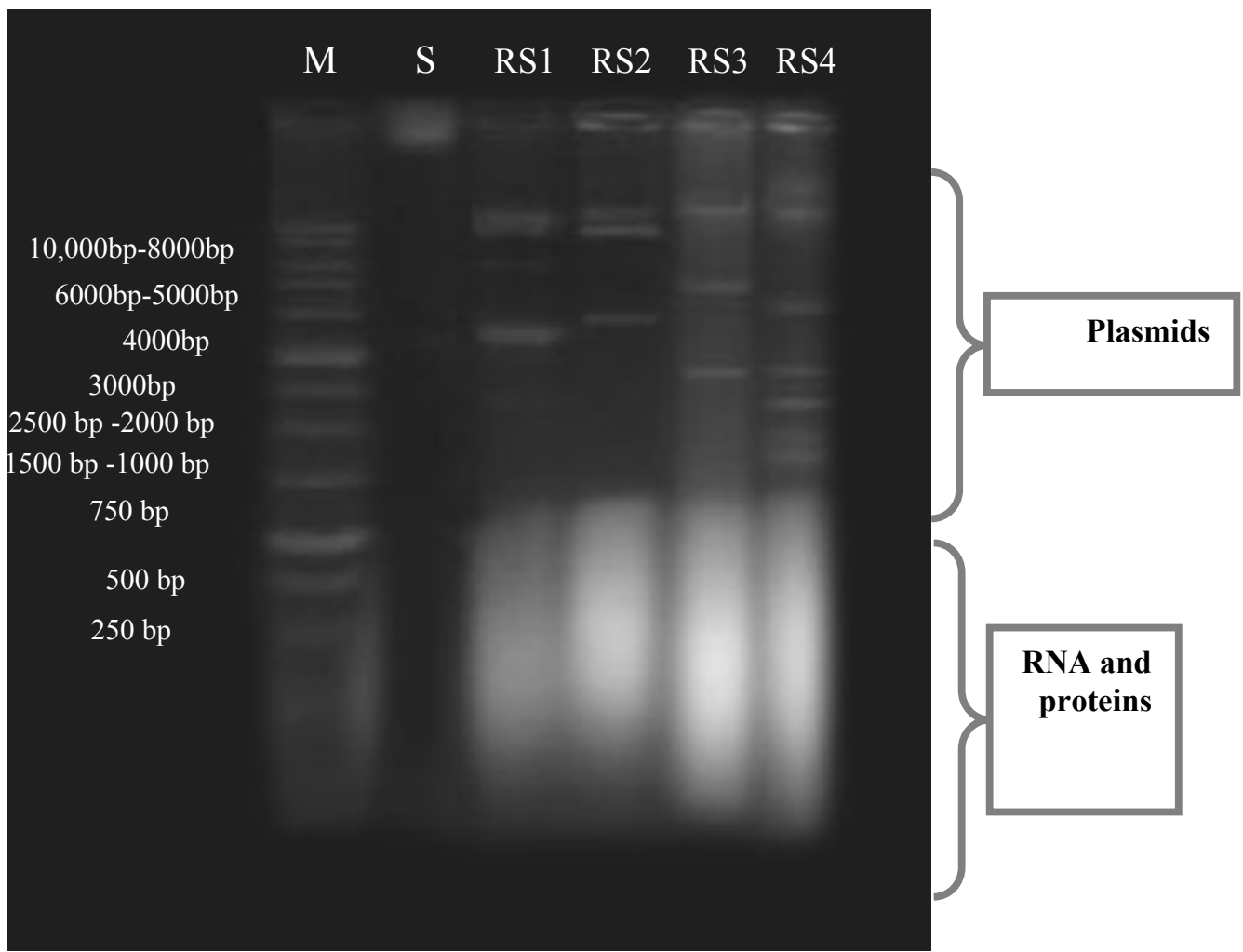

Fig (3): Plasmid Profile of RS1, RS2, RS3 and RS4 on agarose gel (0.8\%) and voltage $60 \mathrm{~V}$ for 2.5hrs

Lane M: represent marker

Lane S: represent DNA of E.coli MM 294 Which considered as standard strain .

From top to bottom RS1 isolate: pRS11, pRS12, pRS13 and pRS14 plasmid band.

RS2 isolate: pRS21, pRS22 and pRS2 plasmid band.

RS3 isolate: pRS31, pRS32 and pRS33 plasmid band.

RS4 isolate: pRS41, pRS42 pRS43, pRS44, pRS45, pRS46 and pRS47 plasmid band.

\section{Plasmid Curing}

Plasmid curing of bacterial isolate was used to know whether the gene(s) responsible for antibiotic resistance is located on the plasmid or chromosomally encoded, for this purpose, many attempts were done in order to cure plasmid DNA of locally isolates E.coli, P. mirabilis, K. pneumonia and P. aeruginosa by using ethidium bromide as a curing agent according to procedure described by [19]. Results in Table (2), showed that the sublethal concentration of ethidium bromide that allows the growth of RS1, RS2, RS3 and RS4 were 800, 1000, 800 and $1000 \mu \mathrm{g} / \mathrm{ml}$ respectively

Table (2): Effect of Ethidium Bromide on the growth of RS1, RS2, RS3 and RS4

\begin{tabular}{ccccc}
\hline $\begin{array}{c}\text { Ethidium } \\
\text { bromid }\end{array}$ & \multicolumn{4}{c}{ Growth } \\
$\mathbf{0}$ & +++ & +++ & +++ & +++ \\
$\mathbf{2 0}$ & ++ & ++ & ++ & ++ \\
$\mathbf{5 0}$ & ++ & ++ & ++ & ++ \\
$\mathbf{1 0 0}$ & ++ & ++ & ++ & ++ \\
$\mathbf{2 0 0}$ & + & + & + & + \\
$\mathbf{2 5 0}$ & + & + & + & + \\
$\mathbf{3 0 0}$ & + & + & + & + \\
$\mathbf{4 0 0}$ & + & + & + & + \\
$\mathbf{8 0 0}$ & \pm & + & \pm & + \\
$\mathbf{1 0 0 0}$ & - & \pm & - & \pm \\
$\mathbf{1 6 0 0}$ & - & - & - & - \\
\hline
\end{tabular}

Where: $(-)$ : no growth $(0 \%),( \pm)$ : slight growth $(25 \%-20 \%),(+)$ : moderate growth $(50 \%-30 \%)$, $(++)$ : good growth $(90 \%-70 \%),(+++)$ : very good growth $(100 \%)$ 
The mode of action of ethidium bromide in curing of plasmid DNA is the inactivation of plasmid DNA replication during cell division, which leads to the presence of plasmid-less cell in the next generations. Furthermore ethidium bromide was a good agent in curing of plasmid DNA, if it is compared with physical and other chemical agents [27].

This experiment was performed using $100 \mathrm{ml}$ of cultures incubated with different concentrations of ethidium bromide were taken and incubated for $24 \mathrm{hrs}$ at $37^{\circ} \mathrm{C}$ to determine the sub-lethal concentration of ethidium bromide .

From this treatment, appropriate dilutions were made and spreaded on nutrient agar plates. One hundred colonies were selected and each one of these colonies were grown in the defined medium containing different antibiotics with AM,CN,CL,C,NA,SXT,P,TE,CTX for RS1, AM,CN,S,C,SXT,P,TE for RS2, AM,CN,C,SXT,P,TE,CTX for RS3 while AM,CN,CL,C,SXT,P,TE,CTX for RS4 in order to determine the cured colonies, which lost its ability to grow in this defined medium, the obtained cured colonies were retested in this medium to ensure losing their ability to grow.

Results showed that most of RS1 colonies were still resistant to these antibiotics, while few colonies became sensitive to AM, CN, TE, P and CL, while RS2 colonies became sensitive to AM, CN, TE and P, RS3 colonies fail to grow on plates containing AM, TE, P and CTX, finally RS4 colonies fail to grow on plates containing AM, CN, TE, P and $\mathrm{C}$. This may due to plasmid curing which caused by the effect of ethidium bromide as a curing agent and as it was mentioned by [28].

From these results it can be concluded that resistance to ampicillin, tetracycline, gentamycin and pencillin for (RS1, RS2, RS3, RS4), cephalexin for RS1, cefotaxime for RS3 and chloramphenicol for RS4 were located on plasmid DNA (plasmid encoded phenotypes), while other antibiotic phenotypes were chromosomally located.

To confirm this result, cells that suspected to be cured were taken and grown in trypton soya broth for $24 \mathrm{hrs}$ at $37^{\circ} \mathrm{C}$ with shaking ( $150 \mathrm{rpm}$ ), and then plasmid profile was examined by extraction of plasmid DNA using alkaline lysis method.

Results in figure (4) showed that after the curing, RS1isolate represented only one band which was named as pRS14. Antibiotic sensitivity to this isolate indicated that was the reason for losing three plasmid.

As for the two isolates RS2, RS3 the loosing of all plasmids after the curing caused losing a number of resistance properties (AM, CN, P,TE) for $P$. mirabilis and $K$. pneumonia that they were carried by chromosome not by plasmid.

While for RS4 isolate, five plasmid bands were lost after curing, and only two bands shown in fig (4) which were named as pRS43 and pRS45. Losing five plasmid bands might indicate retaining of the isolate to be sensitive to the following antibiotics (AM, $\mathrm{CN}, \mathrm{P}, \mathrm{TE}, \mathrm{C}$ ), but resistance to others (STX, CL, CTX) which might be carried on the other two plasmid bands. 


\section{M $\quad$ RS1 RS2 RS RS4}

Plasmids

Degraded RNA

and proteins

Figure (4): Gel electrophoresis of total DNA extracted from isolates(RS1, RS4) after curing by ethidium bromide. Agarose concentration $0.8 \%(\mathrm{~W} / \mathrm{V})$ and voltages $60 \mathrm{~V}$ for 2.5 hours.

\section{References}

1. Awaness, A. M., Al-Saadi, M. G. and S. A. Aadoas. (2000). Antibiotics resistance in recurrent urinary tract infection. Kufa medical Journal. 3:159.

2. John, W. W. (2001). Catheter-associated urinary yract infections. International J. of Antimicro. Agents. 17:299-303.

3. Stamm, W. E. (1999). Catheter-associated urinary tract infections: Epidemiology, pathogenesis, and prevention. Am. J. Med. 91(Suppl 3B):65S-71S.

4. Lemon, P. and K. Burke. (2000). Medical surgical nursing critical thinking in client care. New Jersey: Prentice Hall Heal.

5. Turck, M., Goffe, B. and R.G. Petersdorf. (1999). The urethral catheters and urinary tract infection. J .Urol. 88:834-7.

6. Jarvis, W.R. and W. J. Martone. (1998). Predominant pathogens in hospital infections. J. Antimicrob. Chemother. 29:19-24.

7. Doi, Y., Shibiro, N., Shibayama, K., Kamachi, K, Kurokawa, H., Yokoyama, K., Yagi, T. and Y. Arakawa. (2002).Characterization of a novel plasmid - Mediated cephalosporins and it is genetic environment in an Escherichia coli clinical isolate. Antimicrob. Agents Chemother. 46: 2427 - 2434.

8. Hvidberg, H., Strure , C., Krogfelt , K., Christensen , N., Rasmussen, S. and N. F. Muller. (2000). Development of long - term ascending urinary tract infection mouse mode1 for antibiotic treatment studies. Antimicrob. Agents. Chemother. 44 :156 - 163 . 
9. Greenwood, D., slack, R. and J. Peutherer. (1997). Medical microbiology 5thed . Churchill Liuingstone Inc.

10. Nester, E. G., Denise, G., Anderson, E. R. J. R., Peaesall, N. N. and T. Martha. (2001). Microbiology a human perspective. 3 ed. Macgraw hill companies.

11. Pitout, J. D., Moland, E. S., Sanders, C. C., Thomson, K. S. and S. R Fitzsimmons. (1997). $\beta$-lactamases and detection of $\beta$-lactam. Resistance in Enterobacter. spp. Antimicrob . Agents. Chemother.14: 35 - 39.

12. Hardy, K. (1986). Bacterial plasmid. pp: $1,51,52.65,68,77.2^{\text {nd }}$ ed. American Society for Microbiology, USA.

13. Chakrabarty, A. M. (1996). Microbial Degradation of Toxic Chemicals: Evolutionary Insights and Practical Considerations Features.: 62: 130-137.

14. Lewin, B. (2000). Phage strategies. In: Genes VII. J and L composition Itd. Oxford. P: 319.

15. Makia, R, S. (2007). Biofilm Production as a Virulence Factor in Uropathogenic Bacteria and Yeasts M.Sc. Thesis, Collage of Science of Al- Nahrain university.

16. Atlas, R. N., Brown A. E. and L. G. Paks. (1995). Laboratory Manual Experimental Microbiology. $1^{\text {st }}$ edition. Mosby. USA.

17. National Committee for Clinical Laboratory Standards. (1994). Performance standards for antimicrobial disk susceptibility tests. 5th informational supplement. Villanova, PA: National Committee for Clinical Laboratory Standards.

18. Santos, D. A. and J. S. Hamdan. (2005). Evaluation of Broth Microdilution Antifungal Susceptibility Testing Conditions for Trichophyton rubrum. Journal of Clinical Microbiology. 43(4): 1917-1920.

19. Maniatis, T., Fritch, E. F. and J. Sambrook. (1982). Molecular cloning. A laboratory Manual, Cold Spring Harbor Laboratory, NewYork.

20. Sambrook, J., Fritsch, E. F. and D. Maniatis. (1989). Molecular cloning, 2nded. Cold spring Harbor Laboratory Press, N. Y.

21. Trevores, J. T. (1986). Plasmid curing in bacteria. FEMS Microbiol. Rev.: 32: 149-157.

22. Salzono, G., Villani, F., Pepe, O., Sorrentino, E., Moschetti, G., and S. Coppola. (1992). Conjugal transfer of plasmid-borne bacteriocin production in Enterococcus faecalis 226NWC. FEMS Microbiol. 99: 1-6.

23. Sotto, A., Boever, C., Fabbro-peray, P., Gouby, A., Sirot, D. and Jourdan, J. (2001). Risk factors for antibiotic-resistance Escherichia coli isolated from hospitalized patients with urinary tract infections: a protective study. J. Clini. Micro. 39(2):439-444.

24. Malkawi, H. I. and M. T. Youssef. (1996). Characterization of Escherichia coli isolated from patients with gastrointestinal infections in northern Jordan: Antibiotic resistance and plasmid profiles. J. Res. 11:172-192.

25. Godfrey, H. and H. Evens. (2000). Catheterization and urinary tract infections. Microbiology. Br. J. Nursing. 9:982:90.

26. Birnboim, H., and J. Doly. (1979). A rapid alkaline extraction procedure for screening recombinant plasmid DNA. Nucleic Acid Res. 7:513-523. 
27. Hohn, B., and D. Korn. (1969). Segregation of a sex factor with the E. coli chromosome during curing by acridine orange. J. Mol. Biol. 45: 385-396.

28. Bouanchaud, D. H., Scavizzi, M. R. and Y. A. Chabbert. (1969). Elimination by ethidium bromide of antibiotic resistance in Enterobacterceae and Staphylococci. J. of General Microbio. 54: 417-425. 